\title{
MATERNAL HEALTH AMONG WORKING WOMEN: A CASE STUDY IN THE MEXICAN-U.S. BORDER*
}

\author{
By \\ Norma Ojeda de la Peña** \\ Gudelia Rangel**
}

\begin{abstract}
This work is a description of the differences in maternal health among women of the wage-earning class along the Mexican/United States border in Tijuana, Baja California. The sudy analyzes the specific case of women using the services of the Mexican Institute of Social Security (IMSS), breaking up the sample according to their employment and level of physical labor on the job in industrial, business, and service sectors. The study is based on information from a survey tilled, "Social Conditions of Women and Reproductive Health in Tijuana". This was a post-partum survey administered to a total of 2,596 obstetrical patients seen at the GynecologyObstetrics hospitsl of the Tijuana IMSs office during the spring of 1993. The results indicate differing maternal health conditions among workers, in relation to some of the factors considered risks for infant and maternal health.
\end{abstract}

\section{RESUMEN}

Este trabajo es una descripción de las diferencias en salud matema entre las mujeres de la clase trabajadora a lo largo de la frontera México-Estados Unidos, en especial la ciudad de Tijuana, Baja California. El estudio analiza el caso de mujeres que usan los servicios del Instituto Mexicano del Seguro Social (IMSS), terminando el ejemplo de acuerdo con su empleo y el nivel de trabajo físico en los sectores industrial, empresarial y de servicios. El estudio está basado en información de una encuesta intitulada "Condiciones sociales de las mujeres y salud reproductiva en Tijuana". Ésta fue una encuesta aplicada a un total de 2596 pacientes posparto, en el hospital de gíneco-obstetricia del IMSS en Tijuana, durante la primavera de 1993. Los resultados indican diferentes condiciones de salud materna entre las trabajadoras, en relación con algunos de los factores considerados de riesgo tanto para la salud del infante como de la madre.

\footnotetext{
* This paper is part of a research project supported by the John D. and Catherine T. MacArthur Foundation. "Social Condition and Women's Reproductive Health in Tijuana, B.C., México", conducted by Norma Ojeda de la Peña, El Colegio de la Frontera Norte, 1993. ** Department of Social Studies, and Department of Public Health Studies, El Colegio de la Frontera Norte.

This article was accepted to be published in January, 1997.
} 


\section{INTRODUCTION}

The economic dynamism of the Mexico/United States frontier during the last two decades has generally been accompanied by a trend toward a concentration of Mexican population of both sexes of working age. This is a consequence mainly of the numerous migrant flows that come from different places in the Mexican interior. Some came in search of opportunities to work in the growing industrial sector of border cities on the Mexican side; others cross the border as legal or undocumented workers in the neighboring country.

The service and business sector continues to represent the most important outlet for female employment in Tijuana, not only because it is this sector which has traditionally employed more women, but also because this sector of the economy has been strengthened by growth, and diversified by local demand for services. In 1987, services and trade accounted for $70.8 \%$ of the total economically-active population (PEA), and $72.8 \%$ of the feminine PEA (Cruz, 1990).

However, changes in the job markets of border cities have engendered a high feminine labor force in industry, as in the case of Tijuana, Baja California. This city has seen intensive use of female workers, especially in factories (maquiladoras), so that in 1987 this sector of Tijuana's economy accounted for $26.2 \%$ of the total economically-active population (PEA), and $25.3 \%$ of the feminine PEA (Cruz, 1990).

Forecasts for 1995 in Tijuana are for $27.5 \%$ of the total PEA to be in the industrial sector, and for $71.6 \%$ to be represented by services (Carrillo, et al., 1991). The growth of these two sectors in Tijuana's economy leads us to suppose that the proportion of the feminine PEA in industry and services also should see a consequent increase.

These changes in the economy, and the phenomenon of migration have shocked the demographic structure and dynamics of the local population, marking it with characteristics that make it stand out from the rest of the country. Insofar as the feminine population goes, a previous study identified some characteristics that define a socio-demographic profile that reflects certain contradictions in the living conditions of border women (Ojeda, 1994). These characteristics can be summarized as follows:

On the border there is a greater proportion of women of working ages, as compared to the national average. This is more accentuated in Tijuana, in comparison with the totals of other border municipalities. In the areas of education and employment, women of the northern border also bave higher levels of schooling and rates of employment that the national average for all Mexicans. However, this situation is also more salient in 
the case of Tijuana as compared to a total of border women. In this city, women on the average have still more education and the employment rate is higher.

The proportion of single women aged 11 years and older in the border region is similar to that for the country overall. On the other hand, there are notable differences between these two settings conceming the marital structure of ever-married women.

In the border region there is a higher proportion of women in common marriages than nationally. Apparently, the number is even higher in Tijuana, which has the highest relative number of women living in consensual unions. There is also a slightly higher proportion of divorced and separated women in the border region than in the rest of the country. Finally, census information identified a higher percentage of unwed mothers along the border, and especially in Tijuana, in comparison with the rest of the country.

These characteristics, on the whole, indicate better educational conditions and higher labor force participation among women along the border, particularly in Tijuana. But they also indicate that the latter group shows lower domestic stability than the national average.

The growing presence of women in Tijuana has also been characterized by an accompanying concentration of the female population not only in their working years, but also at their principal reproductive age, chiefly between 15 and 34 years of age. The social and demographic consequences that unfold from this are various and complex, but are of particular importance in regard to their impact on the demand for medical services, especially those for reproductive health services.

Here, as in other parts of Mexico, the public health institutions are those which provide the medical care needs and hospital care for the great majority. The Mexican Institute of the Social Security (IMSS) is the government institution that provides health care to private-sector wage-earners and their dependents. This salaried population does not inelude the poorest social groups in Tijuana. However, that does not mean that those on salary may not have important economic limitations, especially in the case of female industrial workers and manual workers in the tertiary sector.

Tijuana is one of the Mexican cities with greater problems in providing adequate urban services. There are huge gaps in the completion of roads and streets, and in availability of basic services such as running water generally, and drinking water in particular. The large part of urban shantytowns do not have drainage; there is an important shortage in available housing, and dwellings commonly lack running water and indoor toilets. 
These characteristics in the habitat of the Tijuana population translate into social and living conditions that are far from desirable for the majority, in spite of booming economic conditions for the overall region. This applies not only to marginal groups of Tijuana's population - who, of course, are the most affected- but also includes the salaried population, among whom number an important proportion of migrants with very limited resources, and who are forced to live in places that lack even the most elemental urban services. In regard to this, Roberto Sánchez's study (1990) is illustrative of the precarious living conditions of female factory workers, as is the work of Tonatiuh Guillen (1990) on public service and marginality at the border, in which the problem of the precariousness of the migrant population stands out.

On the other hand, the general economic crisis and the policies of economic adjustment of the 1980's not only widened economic and social inequality among Mexicans everywhere in the country (Solidarity, 1991), but also caused serious budget cuts in the public health sector. This has restricted, and in some cases, atrophied the coverage and quality of the National Health Systems, particularly those in provincial areas and in places that are farthest from Mexico City, as is Tijuana.

Unfortunately, there is a wide gap between social development and economic growth in the region, reflected by the presence of important setbacks in the distribution of social benefits among the different social groups of Tijuana's population. Services proffered by the public bealth sector are not an exception. There is a high demand for health services, principally those offered by public health institutions, which has long since surpassed those institutions' capacity to deliver services of optimum quality. This is the case of the Mexican Institute of the Social Security (IMSS), which provides care to the salaried population and, particularly, to the feminine working population. ${ }^{1}$ For example, during fieldwork carried out for this study, it could be verified that there was excessive demand for hospitalization in IMSs's department of gyno-obstetrics; in less than two and one-half months, 2796 women were seen at a single hospital (El Colegio de la Frontera Norte, DEP, 1993).

Thus, a growing feminine migrant population in search of reproductive health services faces precarious social and living conditions, as well as a public health service system whose mandated abilities to deliver health care services to the region's wage-earning population has fallen behind as a result of many causes. These are issues that need be taken into account

1 Approximately $73 \%$ of the total number of births takes place in hospitals of mss in Baja California. Bolettin de Informacion Estadistica, Secretaría de Salud, 1987. 
for a realistic appraisal of the nature in which reproduction of the wageearning population develops, and for this reason, the reproductive health care conditions of its female portion in this part of the country as well.

To get a clear picture of these issues, a survey on social conditions of women and reproductive bealth was conducted in Tijuana. All women entering IMSs's Gynecology-Obstetrics hospital in Tijuana from March 24 and May 30, 1993 were interviewed. This was done to ascertain specifically the infant and matemal health conditions among within the group of the workers who belong to this important public health institution.

As already mentioned, IMSs is a public health institution that operates throughout the country and provides hospitalization and general medical care for the private sector wage-earning class and its dependents. Accordingly, the population interviewed is composed of wives, daughters and mothers of working males, as well as the female workers themselves, and their mothers and daughters who were prompted health reasons to go to the hospital for gynecological-obstetrical medical care during the indicated period.

The information was gathered as an integrated, continuous record that combines demographic, social and reproductive health data obtained from patient interviews, using a standardized questionnaire. In addition, a systematically prepared extract of the patient's hospital record was used. In this manner, there was a total of 2796 interviews of women who sought treatment at the hospital for the following reasons: delivery, abortion, threat of premature birth, threat of abortion, infections or complications related to pregnancy, obstetric surgery, infections unrelated to pregnancy, and sterilization. A total of 2596 women were treated by the hospital for reasons relating to pregnancy.

This work has been developed solely from the information regarding these 2596 pregnant women. It describes the current state of maternal and infant bealth in Tijuana among those females of the wage-earning social class who sought medical services from IMSs. It is therefore, a differential analysis of morbidity suffered during, and as a result of, pregnancy, and analyzed according to the women's economic participation; and secondly as to the labor-intensiveness of employment among industrial and service employees.

\section{BACKGROUND}

During the woman's gestation period occurs a series of physiological changes that distort normal functions of certain organs and corporal systems. The progressive increase in the size of the pregnant uterus, hormonal changes, and the increase in metabolic demands destined for the 
baby's development can umleash pathological processes both of an infectious and non-infectious nature. Such processes are viewed as specific ailments for the duration of the pregnancy,

However, as Ana Langer reflects, in her citation of Hartman and other authors,

the pregnancy, delivery and puerperia in itself do not cause health problems to women; but when they happen in a unfavorable environment, as are precarious living conditions, the lack of knowledge about human reproduction, cultural standards that block early treatment, lack of economic resources, maternal malnutricion, the wrong quality and the lack of availability and access to health services, then having a baby become a high risk event for women. (Langer, 1993:222).

Sociologically, motherhood and pregnancy itself are valued in different ways and have different meanings among women of different social groups, even within the same country. Many factors contribute to this. Among them are differences in educational levels of women and their spouses, their economic conditions, their social values, the cultural context in which they developed, their labor history, and other spheres that have to do with women and their mates. The study accomplished by Brigida García and Orlandina De Oliveira (1991) on work and family life in Mexico is illustrative in this regard.

In spite of all these differences, we consider that most women would wish - when presented with the oportunity - to have a healthy pregnancy and therefore, a pregnancy free of diseases that could affect their lives or even cause death. We believe that when problems occur, they is due to situations that are beyond the women's control, or are due to economic, social or psychological difficulties, or simply ignorance that puts women under conditions of risk to reproductive health.

Also concurring with Langer, are Leslie and Gutierrez, who state:

reproductive health is the state of complete physical, mental and social welfare during the reproduction process. This well-being reacts to economic conditions ..., the living conditions of women, their status in society and to demographic factors. (Langer, 1993:222).

If this is so, then these macro-social factors are those which should be identified as determinants of divergent conditions in the reproductive health of women in any society. In this sense, a factor that is ever gaining more importance is the work women do, and its effects on their reproductive health. 
This factor would seem obvious. However, it presents certain analytical difficulties regarding its character as a predictive factor of reproductive health. In this regard, Alejandro Córdova (1989) very correctly outlines the difficulties in identifying a unilateral connotation for the relationship between women's work and their health. According to this author,

upon the woman's entry into the occupational world there are potentially favorable elements to bealth, as could be the procurement of an income that widens access to consumption, the incorporation of certain benefits, the companionship of co-workers; but there are also potentially harmful elements, as the exposure to numerous physical, chemical, biological and phsyiosociales risks related to labor activity, as well as the new burden that the simultaneous development of domestic labors, among others, can represent. But it is not easy to identify to where the balance of this combination results in benefits or to the detriment of health levels of women who are so situated. (Córdova, 1989:228).

Sylvia Guendelman (1993) also concedes the difficulties of identifying a single dimension - negative or positive - in the relationship between work and female health as a rule. This author also finds more positive factors of the effects of work on female health among workers in an empirical study applied to women employed in Tijuana's maquiladora industry. A review of the literature on the topic, however, shows evidence of damage to maternal and infant health in groups chosen from the female working population and their children, as in the case of female wageearners of the maquiladora industry. In particular, the findings of Catalina Denman's (1990a, 1990b) research on underweight births among factory workers in Nogales, Sonora is illustrative. This same author also indicates the presence of different social schemes between maquiladora workers and service workers in relation to the probability of under-weight births.

The need to know and understand the variety of factors that act against workers' reproductive health has led researchers to include other types of traits in addition to those strictly related with the woman's occupational activity in the analysis. Among these are those which refer to the personal, family and social living conditions of workers (Lara, 1993), and those related to the environment, maternal and infant health implications (Garza, 1993). Another type of issue includes the mistaken perception of symptomology common during pregnancy (Salinas, 1991).

The advisability of examining the weight of every one of these and other factors in determining risks to reproductive health is undeniable. 
However, it is also indispensable to have a broader empirical hnowledge of the separate performance of reproductive health between women workers from diverse social groups and in different regional contexts. It is precisely with this intention that the present work is developed: to make a contribution to the knowledge of the variety of situations that prevail among wage-earners of the border city of Tijuana.

\section{SOCIAL AND DEMOGRAPHIC PROFILE OF THE WOMEN IN THE STUDY, AND REPRODUCTIVE HEALTH BACKGROUND}

\section{Social and demographic characteristics}

As was indicated previously, this is a young population, concentrated in the reproductive and productive ages, so that $80 \%$ of the pregnant women included in this study were between 15 and 29 years of age when interviewed. The information that is presented in Table 1 indicates similar age distribution between among the subpopulations of housewives and overall workers. However, among workers, the proportion of those younger than 20 years of age for non-manual workers contrasts sharply with a difference of 8 percentage points as compared to manual workers.

Looking at marital structure, it was previously indicated by Ojeda (1994) that Tijuana has a relatively higher number of women living in consensual unions in comparison, not only with the nation, but also with respect to the overall border region. More than a third of the women in each group identified themselves as living in such unions, although this was higher for workers. Also, the number of working women who are partnerless because of divorce or separation, or who are single (See Table 1), draws some attention. For workers, we see almost $7 \%$ more women in consensual unions and $12 \%$ more single mothers than among housewives, indicating weaker conjugal stability during the course of the pregnancy for an important number of female workers, particularly those employed in manual labor.

With respect to education, also Ojeda (1994) has already indicated that Tijuana has a population relatively more educated than in the rest of the nation or even in the northern border region. Within this context, the feminine population studied presents levels of schooling still higher since it is largely composed of the city's industrial and service workers. Thus, as expected, female workers have more education that homemakers. It is also clear that among workers, those in non-manual activities are the most educated, showing a proportion of women with more than eight years of education three times that of manual workers. 
TABLE 1. Social and demographic characteristics of pregnant women aged 15-49 years, and their households in IMSS-Tijuana, Mexico (\%).

\begin{tabular}{|c|c|c|c|c|}
\hline \multirow[t]{2}{*}{ Caracteristic } & \multicolumn{3}{|c|}{ Working women } & \multirow[b]{2}{*}{$\begin{array}{c}\text { Housewives } \\
\text { (1410) }\end{array}$} \\
\hline & $\begin{array}{c}\text { Manual } \\
(707)\end{array}$ & $\begin{array}{c}\text { Non-Manual } \\
(479)\end{array}$ & $\begin{array}{c}\text { Total } \\
(1186)\end{array}$ & \\
\hline \multicolumn{5}{|l|}{ 1) Age } \\
\hline 15-19 years & 20.0 & 12.3 & 16.8 & 19.3 \\
\hline $20-24$ years & 37.8 & 39.0 & 38.1 & 37.5 \\
\hline $25-29$ years & 23.6 & 27.6 & 25.5 & 24.2 \\
\hline $30-34$ years & 10.3 & 12.5 & 11.1 & 11.6 \\
\hline $35-39$ years & 5.5 & 6.7 & 6.0 & 4.0 \\
\hline $40-49$ years & 2.8 & 1.9 & 2.5 & 3.4 \\
\hline \multicolumn{5}{|l|}{ 2) Marital Status } \\
\hline Consensual Union & 47.0 & 32.2 & 41.0 & 34.8 \\
\hline Married & 39.0 & 55.3 & 45.6 & 63.8 \\
\hline Without Spouse & 14.0 & 12.5 & 13.4 & 1.4 \\
\hline \multicolumn{5}{|l|}{ 3) Education } \\
\hline $0-5$ years & 16.7 & 6.1 & 12.6 & 17.7 \\
\hline $6-8$ years & 71.4 & 52.5 & 63.4 & 69.4 \\
\hline 9 and more & 11.9 & 41.4 & 23.8 & 12.9 \\
\hline \multicolumn{5}{|l|}{ 4) Place of Birth } \\
\hline \multicolumn{5}{|l|}{ * Baja California or } \\
\hline United States & 17.9 & 25.5 & 20.9 & 25.6 \\
\hline $\begin{array}{l}\text { * Other Place of } \\
\text { Mexico or Country }\end{array}$ & 82.1 & 74.5 & 79.1 & 74.4 \\
\hline \multicolumn{5}{|l|}{ 5) Husband's Occupation } \\
\hline Manual & 83.3 & 58.6 & 73.3 & 74.2 \\
\hline Non-manual & 16.7 & 41.4 & 26.7 & 25.8 \\
\hline \multicolumn{5}{|l|}{ 6) Breadwinner } \\
\hline Husband & 33.9 & 28.0 & 31.7 & 96.4 \\
\hline She/Couple & 61.8 & 69.1 & 64.5 & 1.5 \\
\hline Other & 4.3 & 2.9 & 3.8 & 2.1 \\
\hline
\end{tabular}

The presence of migrants in Tijuana is obviously reflected in the predominantly non-border origin of the women interviewed, especially those working in manual activities. In none of the groups did women born in Baja California or in the United States account for more than $26 \%$ of the total. 
The question regarding spouse's employment, where applicable, solicited information about household economic conditions, and identified principal contributors to household income. A great overall similarity in the employment of the spouses of both housewives and female workers was found. As seen in Table 1, three-quarters of the spouses of both groups of women have manual occupations. This was to be expected, since IMSS has traditionally been the main health provider of the blue-collar workers in Mexico. On the other hand, there is a interesting difference between female manual and non-manual workers. For non-manual workers, the number of women married, or in union with men engaged in non-manual employment, is more than double that for manual workers.

Finally, a result that was expected and is worthy of emphasis, is the important contribution female workers make to their household economies. $65 \%$ said they alone, or together with their spouse, were the principal contributors to the family economy. These circunstances are more notable among women in non-manual employment. In contrast, husbands are the only breadwinner in $96.4 \%$ of the housewives's households.

\section{Conjugal cycle, fertility and background of reproductive health to the current pregnancy}

In accordance with their young age distribution, most women interviewed were in the initial stages of their conjugal cycle. The information presented in Table 2 indicates that more than $60 \%$ of women in all groups claimed to have less than 6 years of spousal co-habitation, regardless of legal marital status.

In addition, more than $80 \%$ of women in all groups had no more than three live births. Within this range some interesting variations are observed between the fertility of housewives and that of female workers. While more than $50 \%$ of workers have only one child, $50 \%$ of housewives have between two and three children. Also, a greater proportion of manual workers have more than one child, as compared to non-manual workers.

Lower fertility among wage-earning women is widely documented in the literature for developed as well as for developing countries; similarly, there is lower fertility among women with higher education. For this reason, it is not surprising that non-manual workers in spite of an younger age distribution, have a lesser number of children than the other two groups.

Table 2 also presents the results for women with at least one pregnancy terminating in miscarriage, abortion or still-birth; the sequence number of current pregnancy and length of the last completed interbirth interval. 
TABLE 2. Charactetistics of the actual pregnancy, years of marriage and fertility of women aged 15-49 years in IMSs Tijuana (\%).

\begin{tabular}{lrrrr}
\hline \multirow{2}{*}{ Characteristic } & \multicolumn{3}{c}{ Working women } & \\
\cline { 2 - 3 } & Manual & Non-manual & Total & Housewives \\
\hline 1) Years of Marriage & & & & \\
0-2 years & 43.2 & 48.3 & 45.2 & 40.6 \\
3-5 years & 18.4 & 17.0 & 17.9 & 25.8 \\
6 and more & 38.4 & 34.7 & 36.9 & 33.6 \\
2) Live Births & & & & \\
0-1 & 51.1 & 61.6 & 55.3 & 34.1 \\
2-3 & 35.1 & 31.1 & 33.4 & 50.0 \\
4 and more & 13.8 & 7.3 & 11.3 & 15.9 \\
3) With at least one & & & & \\
miscarriage, abortion & & & & \\
or still-born & & & & \\
4) Birth Order & 27.0 & 23.6 & 25.7 & 23.5 \\
1St. & & & & \\
2Rd.-3Th. & 40.6 & 50.5 & 44.4 & 26.1 \\
4Th.or more & 39.9 & 37.2 & 38.7 & 50.6 \\
5) Last Interbirth Interval & 19.5 & 12.3 & 16.9 & 23.3 \\
-17 months & & & & \\
17-27 months & 7.7 & 5.2 & 6.7 & 13.8 \\
28 and more & 85.6 & 88.2 & 86.6 & 72.4 \\
6) Prenatal Care & & & & \\
0-3 times & 8.1 & 4.3 & 6.8 & 18.8 \\
4-5 times & 33.3 & 31.4 & 32.5 & 38.4 \\
6 and more & 58.6 & 64.3 & 60.7 & 42.8 \\
\hline
\end{tabular}

Source: Survey "Condición Social de la Mujer y Salud Reproductiva en Tijuana, B.C.". Norma Ojeda, et al. (1993).

Notes:

a Total number of live births including for the actual one.

b With at least one miscarriege, abortion or still-birth during the woman's reproductive life.

c Closed interbirth interval by the actual event (live birth, miscarriage, abortion or still-birth). 
First, it is striking that around one-fourth of women in all groups have had at least one miscarriage, abortion or still-birth in their child-bearing history. Making the comparison between housewives and workers as a whole, we see that there is little difference between these two groups in terms of the proportion of women with such a background. Nevertheless, between these two groups there are extraordinary differences in the number of live births. This allows us to deduce that in comparison with workers, housewives exhibit greater fertility, although they suffered miscarriages, abortions or still-births in almost the same proportion.

On the other hand, the workers group, those with manual occupations have the highest numbers of miscarriages, abortion or still-births, about $27 \%$. This is in spite of a slightly younger age distribution than other workers.

Next, we come to the order of occurrence for the current pregnancy - our topic of study from here on-. Table 2 also shows that the current pregnancy is more commonly the first in the reproductive history of workers than of housewives. $44 \%$ of workers are new mothers, as compared to $26 \%$ of housewives. Among workers, this is the first pregnancy for approximately $10 \%$ more, proportionally, of non-manual wage- earners than of manual workers.

Another important characteristic to examine is the length of the last inter-birth interval. One of the factors which appears most often in the literature of risks to maternal and infant health is the duration of intervals between pregnancies. As an approximation, this study steps away from considering the closed interval between the last live birth and the actual pregnancy outcome - be it a live birth, still born, miscarriage or abortion. All birth orders are included in the estimation.

The pertinent information Table 2 indicates that housewives show an elevated proportion of very short intervals, less than 17 months, for almost $14 \%$ of the cases. To their comparative advantage, workers show half the amount of such cases, and thereby, lower conditions of high risk due to this factor.

Taking into account intervals of less than 28 months, not so short, but still contributing to high risk conditions, we observe that the number of cases at risk is doubled in all groups, with housewives standing out againt at almost $27 \%$ of their cases. Manual workers show the greater frequency of cases among salaried workers, with $14 \%$. Note that this last figure is less than half of that for housewives.

The last characteristic consider is pre-natal medical care received. To analyze this we recorded the visits that women made to prenatal care. Based on this indicator, we can also see in Table 2 that housewives again 
show the greatest risk conditions due to inadequate prenatal care. $19 \%$ used this medical service less than four times; the proportion grows to $57 \%$ when we look at those who made no more than five prenatal-care visits.

The position of workers is, in comparison, more favorable, since only $7 \%$ of them made less than four visits to pre-natal care. Nevertheless, accepted medical practice recommends that the woman be examined at least once a month during pregnancy. If we take into account that women are considered to have access to the medical services of IMSS, we expect that this population could have came very close to fulfilling the medical recommendation. But this was far from true among workers. Nearly $40 \%$ made no more than five visits to pre-natal care.

\section{First conclusion}

In summary, it is important to emphasize characteristics of the socio-demographic profile and the background of the current pregnancy for the average of women in each of the groups considered, as described below.

In comparison with workers, we can say that housewives have higher fertility. Consequently, there are fewer first pregnancies among those interviewees. They have only a slightly smaller proportion of miscarriages, abortion and still-births and a larger proportion cases of short, closed birth intervals, and they made fewer visits to receive pre-natal medical care. These two last characteristics clearly allude to comparatively greater risk to infant and matemal health for housewives, when compared to the overall numberof workers,

Among workers, women in manual employment differentiated themselves from non-manual workers by higher fertility, and therefore, fewer cases of first pregnancy. A greater proportion of them have also had at least one miscarriage, abortion or still-birth in their child-bearing history. Comparatively, they show short birth intervals and insufficient pre-natal care in a proportion only slightly higher than non-manual workers. Nevertheless, the sum of these characteristics would lead one to expect an elevated relative number of pregnancies with health problems for manual workers.

\section{MORBIDITY SUFFERED DURING THE ACTUAL PREGNANCY}

\section{Perception of ailments suffered during pregnancy}

In order to evaluate the status of maternal health based on the physical condition of the pregnant woman, information on health ailments during 
the term of the pregnancy was required. We obtained information about some of the most common ailments, (although this is not to say that they were any less serious) that women reported to have suffered during the development of the pregnancy. Some of these are considered to be highrisk factors, depending generally on when they occur during the pregnancy.

From the women's responses regarding ailments suffered, a profile of eight ailments was generated (Table 3 ). Again, analysis is divided between housewives and workers, the latter being again grouped into manual and non-manual workers.

Using a comparative perspective, we focus our attention first on ailments suffered by housewives as compared to workers. We can observe in Table 3 that, with the exception of bleeding, housewives had health ailments in almost the same or higher proportion as workers. Cases of anemia, high blood pressure and swelling of face, hands, legs, and feet are notable among housewives.

TABLE 3. Proportion of women with different type of morbidities during pregnancy in IMSS-Tijuana (\%).

\begin{tabular}{|c|c|c|c|c|c|c|c|c|}
\hline \multirow{3}{*}{$\begin{array}{l}\text { Type of } \\
\text { morbidity }\end{array}$} & \multicolumn{6}{|c|}{ Working women } & \multirow{2}{*}{\multicolumn{2}{|c|}{$\begin{array}{c}\text { Housewives } \\
\text { (1410) }\end{array}$}} \\
\hline & \multicolumn{2}{|c|}{$\begin{array}{r}\text { Manual } \\
(707)\end{array}$} & \multicolumn{2}{|c|}{$\begin{array}{c}\text { Non-manual } \\
(479)\end{array}$} & \multicolumn{2}{|c|}{$\begin{array}{c}\text { Total } \\
(1186)\end{array}$} & & \\
\hline & 18.1 & $(22.7)$ & 23.4 & $(25.0)$ & 20.4 & $(23.6)$ & 22.1 & $(17.6)$ \\
\hline $\begin{array}{l}\text { Intense abdominal } \\
\text { pain }\end{array}$ & 15.7 & $(29.7)$ & 16.1 & (37.7) & 16.0 & $(32.6)$ & 15.9 & (18.8) \\
\hline $\begin{array}{l}\text { Swollen face, legs } \\
\text { and feet }\end{array}$ & 43.8 & $(80.0)$ & 45.1 & $(81.5)$ & 44.4 & $(80.6)$ & 47.9 & $(84.5)$ \\
\hline Bleeding & 18.2 & $(17.1)$ & 22.5 & $(20.4)$ & 20.0 & (18.6) & 13.1 & (32.4) \\
\hline $\begin{array}{l}\text { Trembling/ } \\
\text { Convulsions }\end{array}$ & 2.4 & $(41.2)$ & 1.9 & $(22.2)$ & 2.2 & (34.6) & 2.2 & (48.4) \\
\hline High blood pressure & 8.1 & $(57.9)$ & 11.3 & (61.1) & 9.4 & $(59.5)$ & 10.9 & $(66.9)$ \\
\hline Low blood pressure & 15.1 & $(38.3)$ & 15.7 & $(29.3)$ & 15.3 & (34.6) & 15.0 & $(37,0)$ \\
\hline $\begin{array}{l}\text { Urinary } \\
\text { infections }\end{array}$ & 28.6 & $(37.1)$ & 35.7 & $(29.8)$ & 31.5 & $(33.8)$ & 30.3 & $(49.9)$ \\
\hline
\end{tabular}

Source: survey "Condición Social de la Mujer y Salud Reproductiva en Tijuana, B.C."; Norma Ojeda et al. (1993).

() Number of cases that occurred during: 1) The first three months of pregnancy for the cases of anemia and abdominal pain, and 2) during the last three months of pregnancy for the rest of the morbidities. 
As one looks at sicknesses suffered by workers when they are classified according to the labor-intensiveness of their employment there are reflected certain differences that contradict what would be theoretically expected. For most types of ailments, non-manual workers suffered a greater proportion of health problems during pregnancy. Aside from the category of trembling or convulsions, the figures indicate that non-manual workers had from between 7 and $0.6 \%$ higher indices toward negative health conditions than did manual workers.

The interpretation of these figures, however, leads us to consider first the possibility that we are facing a situation of differences in the quality of answers from the interviewees, and not necessarily differences in ailments suffered. This is especially so when we consider the differences that exist in educational levels for these two subpopulations. We could suppose that non-manual workers, due to their higher educational levels, answered in a more reliable way regarding ailments they suffered during pregnancy. An other factor, different in nature, is a possible negative impact on the maternal health of the less youthful age distribution exhibited by non-manual workers (Table 1). One of these factors or the combination of the two could explain to us the differences exhibited between the two groups of workers in reporting infirmities suffered during pregnancy.

\section{Pregnancy outcomes and under-weight births}

In considering the physical conditions of pregnancy, an indicator that is frequently used to measure the status of infant and maternal health is the birth-weight of live-borns. The information used to estimate this was obtained directly from the hospitable record through what IMSs designates as the "Page of Births and Abortions" filled out by the hospital's medical staff. This guarantees the quality of the information, and accordingly, the reliability of the data.

In Table 4 we present classified data on the outcome of pregancies in three categories. According to the typology used by IMSS: live-births, still-borns and miscarriages, which includes abortions. After that, they show results of birth-weights of surviving live-borns.

For the first type of information, the results indicate a clear situation of advantage for bousewives, with a higher percentage of pregnancies ending in live-births when compared to cases among workers. As a direct consequence, the number of still-borns and miscarriages or abortions is higher among workers, with almost the double the number of such cases. The greater frequency of miscarriages or abortions for workers (approximately $12 \%$, versus about $7 \%$ for housewives) is of some interest. 
TABLE 4. Result of pregnancy and infant birth weight for the present live birth to women aged 15-49 years in IMSs-Tijuana.

\begin{tabular}{lrrrr}
\hline \multirow{2}{*}{ Characteristic } & \multicolumn{3}{c}{ Working women } & \\
\cline { 2 - 3 } & Manual & Non-manual & Total & Housewives \\
\hline Pregnancy's result & $(553)$ & $(358)$ & $(919)$ & $(1158)$ \\
Total & 00.0 & 100.0 & 100.0 & 100.0 \\
Live birth & 85.2 & 90.2 & 87.2 & 92.3 \\
Still-born & 1.2 & 1.1 & 1.2 & 9 \\
Miscarriage & 13.6 & 8.7 & 11.6 & 6.8 \\
or abortion & $(471)$ & $(323)$ & $(801)$ & $(1069)$ \\
Birth weight & 100.0 & 100.0 & 100.0 & 100.0 \\
Total & 96.2 & 96.3 & 96.2 & 95.0 \\
2500 G.and more & 3.6 & 3.7 & 3.7 & 4.7 \\
1000-2499 G. & .2 & & .1 & .3 \\
500-999 G. & & & & \\
\hline
\end{tabular}

Source: Survey "Condición Social de la mujer y Salud Reproductiva en Tijuana,B.C." Norma Ojeda et.al. DEP, Colegio de la Frontera Norte, Spring, 1993.

${ }^{a}$ Multiple births are not included.

Within the group of working women, salaried manual workers show a greater number of miscarriages and abortions: about $14 \%$ in comparison with $9 \%$ for non-manual workers.

The results, however, on birth weights for the total of surviving live-born children in each one of these groups indicates a panorama contrary to that seen above. In this instance, housewives are at disadvantage, having the highest proportion of cases of under weight births. If we consider all births of less than 2500 grams (premature and immature), we get exactly $5 \%$ of these births from housewife mothers in comparison to $3.8 \%$ for all mothers who work. On the other hand, there is practically no difference between manual and non-manual workers as regards this indicator.

\section{Second conclusion}

Considering the three types of indicators of infant and matemal health of those interviewed, we can emphasize two general findings. The first is the contradiction found when using the indicator for ailments suffered for 
the two groups of workers. Non-manual workers reported having had more health problems. The indicator's own nature, however, leads us to doubt the validity of this result because it reflects, perhaps, a perceptual estimation of health rather than the real state of the mother's health.

On the other hand, we are assured of the reliability of the findings obtained on pregnancy outcomes, and of birth-weights of surviving live births, is this information was obtained directly from the medical files of hospital records. Thus, based on the frequency observed from these two indicators we can say that even though the number of pregnancies that end happily in children born alive is greater among housewives than among workers, the greater frequency of underweight births among children of housewives prevents us from asserting that they clearly have better conditions of infant and maternal health than do workers.

In keeping with what was observed previously, housewives show the greater relative number of short birth intervals, and a greater proportion of cases with insufficient pre-natal care. To this, one must add that in spite of the problems with the indicator already discussed, the greatest number of anemia cases reported have been precisely among housewives.

We turn to infant and maternal health conditions among workers. Although their proportion of underweight-births is less than that of housewives, this does not mean that the implications are not serious. The magnitude of registered cases indicates a situation of concern for manual workers as well as for non-manual employees. When we add the fact that workers have a relatively higher number of pregnancies ending in miscarriages or abortion, their condition becomes disturbing, especially for those in manual occupations.

This last finding also fits in with the previous results. Manual workers have the higher number of women with at least one miscarriage, abortion, or still born in their reproductive history; more cases of short, closed birth intervals; and less frequency of instance of prenatal care in the current pregnancy.

\section{CONDITIONS OF INFANT AND MATERNAL HEALTH AMONG WORKING WOMEN IN INDUSTRY AND SERVICE SECTORS}

In order to know a little more of ailments suffered during pregnancy and its impact among workers, it is helpful to separate the women according to the labor-intensiveness in employment and the type of economic activity. Also, it is important to take into account some of the occupational conditions that prevailed during the development of the pregnancy, or during the majority of its term. 


\section{Incidence of disease suffered during pregnancy among workers}

The differential analysis of infants and pregnant or post-partum workers according to employment character must also be accompanied by distinguishing how women are treated in industry as well as in service sectors. The labor demands and the exposure to risks in the workplace are not necessarily the same for all manual and for all non-manual workers. The characteristics of employment in factories are different from those which prevail in the great variety of jobs comprising the service and business sectors, such as small commercial offices, large stores, restaurants, hotels, bars, private offices, etc.

The variety of labor conditions that can exist within these two large sectors of production necessarily should differently affect the workers' maternal health, especially in the case of those in manual occupations. For example, between industrial laborers and manual service workers, there are important differences in work schedules and the possibility of taking breaks. The same differences may exist between non-manual industrial workers and employees in the tertiary sector, as we shall see below.

This sort of comparison between workers helps to control the bias due to differences in educational levels between non-manual and manual workers. This bias influences the quality of answers given by interviewees regarding ailments suffered during pregnancy, and Table 5 indicates that the most frequent ailments among workers was swellings of the face, hands, legs and feet; urinary infections; anemia and bleeding. These conditions occur in less than $20 \%$ of pregnancies among all occupational groups. Following these are cases of intensive abdominal pain and low blood pressure in about $15 \%$ of the total number of workers, although the frequency of those suffering high pressure is also far from neglible.

Table 5 also permits an appreciation of the merit of establishing a comparison between subpopulations of manual and non-manual workers according to the type of economic activity. This would allow a finer assessment of variations in the frequency of occurrence of each type of ailment within the different groups making up the feminine working population in Tijuana.

Anemia is the condition with the greatest range of variation between groups. Even though a fifth of the workers stated they were anemic during pregnancy, this proportion varies noticeably within each subgroup of manual and non-manual workers, according to classification of economic activity. In both groups, workers in services report this health deficiency in greater proportion, varying from 5\% of manual workers to about 13 percentile points among women in non-manual occupations. 
TABLE 5. Proportion of working women with different type of morbidities during pregnancy in IMSs-Tijuana (\%).

\begin{tabular}{|c|c|c|c|c|c|}
\hline \multirow{2}{*}{$\begin{array}{l}\text { Type of } \\
\text { Morbidity }\end{array}$} & \multirow[b]{2}{*}{$\begin{array}{l}\text { Total } \\
(1184)\end{array}$} & \multicolumn{2}{|c|}{ Manual workers } & \multicolumn{2}{|c|}{ Non-manual workers } \\
\hline & & $\begin{array}{c}\text { Industry } \\
\text { (578) }\end{array}$ & $\begin{array}{c}\text { Commercel } \\
\text { Service } \\
(129)\end{array}$ & $\begin{array}{c}\text { Industry } \\
\text { (139) }\end{array}$ & $\begin{array}{c}\text { Comercel } \\
\text { Service } \\
(338)\end{array}$ \\
\hline Anemia & 20.4 & 17.1 & 22.5 & 14.4 & 27.2 \\
\hline $\begin{array}{l}\text { Intensive abdominal } \\
\text { pain }\end{array}$ & 16.0 & 14.7 & 20.2 & 12.2 & 17.8 \\
\hline $\begin{array}{l}\text { Swollen face, } \\
\text { legs and feet }\end{array}$ & 44.4 & 43.9 & 43.4 & 48.2 & 43.5 \\
\hline Bleeding & 20.0 & 17.6 & 21.0 & 21.0 & 23.4 \\
\hline $\begin{array}{l}\text { Trembling/ } \\
\text { Convulsions }\end{array}$ & 2.2 & 1.9 & 4.7 & 2.9 & 1.5 \\
\hline High pressure & 9.4 & 7.3 & 11.6 & 10.1 & 11.5 \\
\hline Low pressure & 15.3 & 14.4 & 18.6 & 12.2 & 17.2 \\
\hline Urinary infections & 31.5 & 28.2 & 30.2 & 27.3 & 39.3 \\
\hline
\end{tabular}

Source: Survey "Condición social de la mujer y salud reproductiva en Tijuana, B.C."; Norma Ojeda, et al (1993).

This situation is also exhibited for other sorts of ailments, though the variation ranges are markedly narrower than those observed for anemia. For example, $16 \%$ of all workers reported having suffered intensive abdominal pain during the pregnancy. However, this ailment occurred in approximately $5 \%$ more salaried manual workers in services, than among other, such workers. The same is true of service workers as compared to industrial workers.

For all categories of infirmities, manual wage-eamers in servicess show higher percentages than for industrial workers, except in the category of swellings of the face, hands, legs and feet. Also among non-manual wage-earners, employees in business and the services have higher incidences of most of ailments listed. The exceptions are again: swellings of the face, hands, legs and feet, as well as cases of trembling and convulsions.

Thus, the results obtained for ailments suffered during pregnancy do not present sufficient evidence to assert that manual workers have had more health problems during pregnancy than non-manual workers. Nevertheless, they do indicate more unfavorable health conditions for workers situated in the business and service sector than for those in industry. 


\section{Pregnancy outcome and underweight births among working women}

The information on pregnancy outcome and birth-weight of live-born children indicates another perspective on infant and maternal health regarding workers in Tijuana. The information in Table 6 confirms findings indicated in the previous section on the greater proportion of pregnancies to non-manual workers ending in live-births, in comparison with those of salaried manual workers, who suffer a greater relative number of miscarriages, abortions and still-births.

Comparison by type of economic activity with this indicator, however, shows us that there are clearly differ conditions of infant and maternal health the group of manual workers but less so among non-manual workers.

Among manual workers, we see that industrial workers as well as manual service workers have the highest actual figures for pregnancies ending in miscarriages, abortion or still births. But this situation is more serious among salaried manual workers in services - with a difference of 2.6 percentage points more in the total number of miscarriages - in comparison with industrial workers. On the other hand, the difference between the two groups of non-manual workers is notably smaller, indicating less heterogeneous conditions of infant and maternal health for them.

By using the low-weight births for live-borns indicator for different groups of workers, the clear condition of beterogeneity in infant and maternal health is again observed for manual workers according to type of economic activity. But, in this instance the industrial workers are the most affected. The percentage of underweight babies is greater among mothers working in industry than among mothers employed in manual activities in business and services. The value are, respectively, 4.1 and 2.6 babies weighing less than 2500 grams at birth for each one hundred live births (See Table 6).

Also, different conditions of infant and maternal health are observed among non-manual workers, where again those most affected are industrial employees, though with variations less pronounced than in the previous case. In this circumstance the percentages are 4.1 and 3.6 underweight births for industrial employees and service employees, respectively.

Similarly, the proportion of underweight live births reflects a more delicate condition of maternal and infant health for women working in industry than for those involved in the tertiary sector. The proportion for workers and non-manual employees in industry with low-weight births is greater than that of manual workers engaged in services. 
TABLE 6. Pregnancy's result and birth weight for the actual live birth of working women aged 15-49 years in IMSS-Tijuana.

\begin{tabular}{|c|c|c|c|c|}
\hline \multirow[t]{2}{*}{ Characteristic } & \multicolumn{2}{|c|}{ Manual workers } & \multicolumn{2}{|c|}{ Non-manual workers } \\
\hline & Industry & $\begin{array}{c}\text { Commerce/ } \\
\text { Service }\end{array}$ & Industry & $\begin{array}{c}\text { Commerce/ } \\
\text { Service }\end{array}$ \\
\hline Pregnancy's result & $(459)$ & (94) & (108) & $(248)$ \\
\hline Total & 100.0 & 100.0 & 100.0 & 100.0 \\
\hline Live-birth & 85.6 & 83.0 & 89.8 & 90.3 \\
\hline Still-born & 1.5 & & 9 & 1.2 \\
\hline \multicolumn{5}{|l|}{ Miscarriage } \\
\hline or abortion & 12.9 & 17.0 & 9.3 & 8.5 \\
\hline Birth weight $^{a}$ & (393) & (78) & (97) & $(224)$ \\
\hline Total & 100.0 & 100.0 & 100.0 & 100.0 \\
\hline ( 2500 and more grs.) & 95.9 & 97.4 & 95.9 & 96.4 \\
\hline (1000-2499 grs.) & 3.8 & 2.6 & 4.1 & 3.6 \\
\hline (500-999 grs.) & .3 & & & \\
\hline
\end{tabular}

Source: Survey "Condición Social de la Mujer y Salud Reproductiva en Tijuana, B.C."; Norma Ojeda et.al, DEP El Colegio de la Frontera Norte, spring, 1993.

${ }^{a}$ Multiple births are not included.

\section{Third conclusion}

The indicators on infant and matemal bealth used to examine the conditions that the different groups of workers exhibit in this regard permit us to conclude two general aspects.

First, the frequency of cases of ailments suffered during pregnancy identify workers in business and services as the most affected group. But apparently, the level of labor intensity is not a decisive factor in determining a greater frequency of illnesses.

On the other hand, the number of pregnancies ending in miscarriage, abortion or still-births, and the proportion of live births of low birth weight coincide in signaling a more precarious infant and maternal health condition for women working in industry, In this case an intensive level of labor in the mother's employment did seem to have a pernicious effect on the outcome of the pregnancy and the babies' weight. 


\section{Workload, age and prenatal care among working women}

Without attempting to explain the previous results, but in the spirit of providing elements that permit us to obtain some understanding of it, information is included on some aspects of the occupational activity of the women during pregnancy, as well as the pre-natal care they received.

The labor characteristics in industry are different from those in the business and service sector. Some of the most important for the purposes of this study are the greater stability in social security rights for workers. This allows them guaranteed access, without additional cost, to medical services with general practitioners and specialists. This is without a doubt an important positive factor in the physical and mental health of future mothers.

In industry however, there is another type of characteristic that can have a pemicious influence on the physical as well as mental health of mothers. There is great rigidity in work routines; the minimal work period is 8 hours a day. Occasionally, women work even more, since putting in overtime is the only available way to increase the salary; the work week is 7 days long, and handling toxic materials is part of normal work. Another factor is the limited possibilities of continuity and promotion for workers within the industry's employment structure, explained in large part by the phenomenon of employee rotation, especially in factories (maquiladoras).

Table 7 shows us that a larger proportion of industrial laborers and employees worked throughout the entire pregnancy than did workers in business and services. It is revealing that an important proportion of workers in all groups continued working during very advances stages of pregnancy. Betwween 28 and $34 \%$ said they continued to work past the seventh month of pregnancy. Outstanding in this regard are the manual and non-manual service workers, compared to industrial laborers and other employees. This can be attributed to health authorities greater vigilance in regard to maternity leave rights in most industrial plants.

The high proportion of pregnant women that worked long work weeks is impressive. More than three fourths of all working women said they put in over 40 hours per week. This is especially so among industrial workers. The proportion reaches $87 \%$ among laborers, and $80 \%$ for other industrial employees. Worse yet is that a quarter of industrial laborers and employees worker longer than 48 hours per week.

Turning to break periods during working hours, we see that in none of the groups does the percentage of workers who said they rested more than before the pregnancy exceed one-fifth. Among laborers, only $13 \%$ had the opportunity to take more work breaks than before the pregnancy. These 
groups are followed by industrial employees and non-manual service workers, both of whom had $20 \%$ of respondents who rested more during the pregnancy (See Table 7).

Another class of factors that could be behind the findings obtained on infant and maternal bealth are presented in Table 7: prenatal care, size of the last birth interval and the age distribution for each group of workers.

On the question of prenatal care, we observe, as previously, that manual workers go less frequently to pre-natal care services. This situation does not change when the type of economic activity is considered, since laborers as well as non-manual service workers show the highest percentages of cases, with less than four visits to the medical office. In this case, however, we can also see that manual service workers present the worse situation at double the proportion experienced by industrial laborers with less than 4 visits to medical control.

On variations among workers in respect to the length of the last birth interval, both groups of manual workers -in industry and servicespresent the highest percentages of cases with short birth intervals. This however, appears to be more accentuated for service workers.

Also it is worth pointing out that the proportion of non-manual workers in services is almost the same as that of the industrial laborers, with about $13 \%$ of cases with a birth interval of less than 28 months.

Finally, a characteristic that we cannot forget to account for, is the distinct age distribution that these different groups of women workers have. It was previously pointed out that manual workers are relatively younger than non-manual workers. When they are broken down according to economic activity we find, as was expected, that industrial workers are the youngest, with $62 \%$ of them less than 25 years of age; other industrial employees follow, with almost $60 \%$ of women younger than 25 years. Although both groups of workers in services have a less youthful age distribution, this especially applies to those in this sector engaged in manual activities.

\section{Fourth and last conclusion}

The overall results obtained on the state of infant and maternal health, labor conditions, demographic characteristics, and prenatal care of separate groups of the working female population allows us to present the following partial conclusion:

The results on differential morbidity suffered during pregnancy among groups of workers appear to be related with age distribution, levels of prenatal care and of the size of the last birth interval. We turn to the 
TABLE 7. Working conditions, age distribution and prenatal care among pregnant working women aged $15-49$ years in IMSsTijuana (\%).

\begin{tabular}{|c|c|c|c|c|c|}
\hline \multirow[t]{3}{*}{ Characteristics } & \multirow{3}{*}{$\begin{array}{l}\text { Total } \\
\text { (1184) }\end{array}$} & \multicolumn{2}{|c|}{ Manual workers } & \multicolumn{2}{|c|}{ Non-manual work } \\
\hline & & Industry & Commercel & Industry & Commer \\
\hline & & (578) & $(129)$ & (139) & (338) \\
\hline \multicolumn{6}{|c|}{ 1) Working during preg } \\
\hline Yes & 92.1 & 93.6 & 88.4 & 90.6 & 91.4 \\
\hline No & 7.9 & 6.4 & 11.6 & 9.4 & 8.6 \\
\hline
\end{tabular}

2) Last month of pregnancy and working

$\begin{array}{llllll}\text { 6th month } & 28.7 & 24.4 & 30.2 & 33.1 & 34.9 \\ \text { 7th month } & 42.4 & 47.2 & 40.3 & 39.1 & 31.0 \\ \text { 8th-9th month } & 28.9 & 28.4 & 29.5 & 27.8 & 34.1\end{array}$

3) Weekly hours of work

$\begin{array}{llllll}40 \mathrm{hrs} . & 21.7 & 13.5 & 34.8 & 20.2 & 31.1 \\ 41-48 \mathrm{hrs} . & 58.4 & 60.1 & 53.6 & 54.8 & 58.7 \\ 49 \mathrm{hrs} \text {. and more } & 19.9 & 26.4 & 11.6 & 25.0 & 10.2\end{array}$

4) Resting time during working hours

*Same as before pregnancy $\quad 82.9$

*More than before pregnancy 17.1

5) Age group

$15-19$ years

20-24 years

25-29 years

30-34 years

$35-39$ years

$40-49$ years

6) Prenatal care

0-3 times

4-5 times

6 and more

7) Last interbirth interval ${ }^{a}$

$\begin{array}{lrrrrr}\text { Less than 17 } & 6.7 & 7.7 & 7.4 & 2.7 & 6.3 \\ 17-27 \text { months } & 6.7 & 6.0 & 10.6 & 7.2 & 6.3 \\ 28 \text { and more } & 86.6 & 86.3 & 82.0 & 90.1 & 87.4\end{array}$

Source: Survey "Condición Social de la Mujer y Salud Reproductiva en Tijuana,B.C." Norma Ojeda, et al. (1993).

a Closed interbirth interval by actual event (live birth, miscarriage, abortion or still-born). 
implications of these factors concerning the physical state of the women during gestation. It is precisely women working in services, especially in manual activities, who said they suffered more ailments during pregnancy, and they were also the group with less prenatal medical care and more cases of short birth intervals, against a more mature age distribution.

On the other hand, the pregnancy outcome, miscarriages, abortions or still-births, as well as the frequency of babies with low birth weight, tend to be more closely related to the woman's labor conditions and history of previous miscarriages in her reproductive history. Industrial workers showed the most severe infant and maternal health conditions statistics based on indicators on pregnancy outcome and birthweights, while at the same time they were exposed to more exhausting labor conditions, especially in the case of industrial laborers.

\section{FINAL COMMENT}

The findings of this study derive from a very general analysis. This should be put to the test in a more detailed study controlling for the multiple intervening effects of social and demographic variables which affect infant-maternal health.

Regardless of its simplicity, the information presents us with an important viewpoint on maternal health for workers beyond from the particular case of Tijuana. It is clear that women who work show important dissimilarities in their maternal health, depending on their place in different economic sectors, but especially dependent on the labor intensiveness of their employment. Therefore it would seem important to consider these two characteristics of female employment together.

This situation resulted within a population of workers that all had access to the same levels of health care through IMSs. The diverse working conditions (whether the job is manual or non-manual) allows us to discriminate between greater or lesser physical exertion demanded of pregnant women during the course of their work. In addition, we must stress the many different forms manual labor may take, considering the whole panorama, from the factory to the many manifestations of the tertiary sector: offices, hotels and restaurants, self-employed street vendors, etc.

As far as the type of employments being an individual socio-economic indicator, we can say that we are talking about workers belonging to diverse social groups; and who are associated with separate education levels and income and; at the same time, are probably linked to distinct qualities of life, values and levels of information about health care, especially reproductive health. 
It is for that reason that an analysis of maternal health risks among women workers should take as its point of departure the differences related to the level of physical labor on the job and its place in the economy. Without these two factors we cannot socially conceptualize the infant-maternal health of working women.

\section{REFERENCES}

CARRILLO V., Jorge, et al. 1991. Mercados de trabajo en la industria maquiladora de exportación: sintesis del reporte de investigación. Secretaría del Trabajo y Previsión Social and El Colegio de la Frontera Norte, Ed. Baja California, Mexico.

CARRILLO J. y Mónica Jasis. 1983. La salud de las obreras en las plantas maquiladoras: el caso de Tijuana. Working paper CEFNOMEX, Baja California, Mexico.

Consejo Consultivo del Programa de Solidaridad. 1991. El combate a la pobreza: lineamientos programáticos, México, El Nacional.

CÓRDOVA C., Alejandro et al. 1987. "Cambios demográficos y sus repercusiones sobre los problemas de salud de la población trabajadora femenina urbana". In: Jennifer Cooper, Teresita de Barbieri et al. Fuerza de trabajo femenina urbana en México, características y tendencias. Universidad Autónoma de México. Porrúa Editorial, Mexico City, Mexico.

CRUZ Pińeiro, Rodolfo. 1990. "Mercados de trabajo y migración en la frontera norte: Tijuana, Ciudad Juárez y Nuevo Laredo" In: Frontera norte. Volume 2, Number 4, July-December, El Colegio de la Frontera Norte, Baja California, Mexico.

DENMAN, Catalina. 1990a. "Industrialización y maternidad en el Noroeste de México" In: Gaceta, El Colegio de Sonora, Number 2, July-September, Sonora, Mexico.

- 1990b. "La salud de las obreras en la maquila: el caso de Nogales, Sonora". In: Guillermo de la Peffa, et al. (editors) Crisis, conflicto y sobrevivencia: estudios sobre la sociedad urbana en México. Universidad de Guadalajara and CIESAS, Jalisco, Mexico.

- 1992. "Indicadores de salud-enfermedad; el caso de riesgo reproductivo en obreras de la maquila". In: Eduardo Menéndez, et al. (editors) Prácticas populares, ideología médica y participación social. Aportes sobre antropología médica en México. Universidad de Guadalajara and CIESAS, Jalisco, Mexico. 
FIGUEROA Damián, Ricardo, et al. 1994. "La infección urinaria y su importancia en la mujer embarazada". In: Enfermedades infecciosas y microbiología. Volume 14, Number 1, Mexico City, Mexico.

GARCÍA, Brígida y Orlandina de Oliveira. 1991. Vivencias sobre la maternidad y el trabajo en sectores medios y populares urbanos. El Colegio de México, Mexico Cíty, Mexico (mimeograph).

GARZA, Victoriano. 1993. Riesgos ambientales para la salud materno infantil en la frontera Estados Unidos-Mexico. Papper presented to the Seminar "Bases para el futuro: la salud de la familia en la frontera mexicano-estadounidense". El Paso, Texas, U.S.

GUENDELMAN, Sylvia. 1993. Mujeres trabajadoras y la industria maquiladora. Papper presented to the Seminar "Bases para el futuro: la salud de la familia en la frontera mexicano-estadounidense". El Paso, Texas, U.S.

GUILLÉN, Tonatiuh. 1990. "Servicios públicos y marginalidad social en la frontera norte". In: Frontera norte, Volumen 2, Number 4, July-December, El Colegio de la Frontera Norte, Baja California, Mexico.

LANGER, Ana, B. Hernández, J. Chirinos y M. Romero. 1993. El impacto de las mujeres matemas sobre la situación familiar. Cuernavaca, Instituto Nacional de Salud Pública.

LARA, Ma. Asunción. 1993. Incorporación de la mujer al trabajo remunerado: repercusiones para su salud reproductiva. In: Ford Foundation "Agenda para la investigación y la acción sobre la salud reproductiva de la mujer en México" (mimeograph).

Oficina Sanitaria Panamericana. 1982. "El enfoque de riesgo en la atención perinatal y materno-infantil" Boletín de la Oficina Sanitaria Panamericana, Volume 92, Number 6, Mexico City, Mexico.

OJEDA de la Peña, Norma. 1994. Reporte técnico de la encuesta "Condición social de la mujer y salud reproductiva en Tijuana, B.C.", Departamento de Estudios de Población, El Colegio de la Frontera Norte (mimeograph).

- 1995. "Perfil sociodemográfico de la población femenina en Tijuana y uso de servicios médicos en salud reproductiva: el caso del IMSS en Tijuana". In: Table Ronde: la Frontiere Mexique-Etats Unis: Mutations Economiquess, Sociales et Territoriales. CREDAL/ORSTOM/COLEF, Editions de L'Heal, Paris, France.

SALINAS M. Ana Ma. et al, 1991. "Percepción de sintomatología común durante embarazo, puerperio y lactancia". In: Salud pública de México, May-June, Volume 33, Number 3. 
SÁNCHEZ, Roberto. 1990. "Condiciones de vida de los trabajadores de la maquiladora en Tijuana y Nogales" en Frontera norte, Volume 2, Number 4, July-December.

Sistema Nacional de Salud. 1992. Recursos y Servicios, Boletín de Información Estadística, Number 12. 